\title{
Medium and Credibility in the African Novel: The Novelistic Vision of G.D Nyamndi and Blessed A. Njume
}

\author{
Andrew T. Ngeh \\ Correspondence: Andrew T. Ngeh, PhD, Department of English, University of Buea, PO Box 63, Cameroon. \\ Received: July 26, 2017 \\ Accepted: August 29, $2017 \quad$ Online Published: September 4, 2017 \\ doi:10.11114/smc.v5i2.2633 \\ URL: https://doi.org/10.11114/smc.v5i2.2633
}

\begin{abstract}
The post-colonial African novelist is committed beyond his/her art to a statement of value. Thus he is not interested in art for art's sake. This study distances itself from Dan S. Izevbaye's 1971 position for a 'suppressed social reference' in literary discourse. The post-colonial novelist believes that he must be socially committed in order to be universally engaged. In his/her novelistic vision, he/she questions the very foundation of the independence of most African nations. There is a consensus amongst African creative writers that the independence of most African countries is a sham because independence means self-determination. George D. Nyamndi in his The Sins of Babi Yar (2012) and Blessed Ambang Njume in his In a Web (2016) set out to bring out the visionary role of a committed writer and his moral obligation to his society. Using the medium of effective communication, the two novelists highlight corruption and the abuse of power as banes to socio-political development in Cameroon in particular and Africa as a whole. Using new historicism and the concept of socialist realism to interpret, evaluate and analyse the two novels under study, the paper explores and highlights the moral responsibility of a committed novelist in post-colonial African society. In this light, this study submits that the law courts, the judiciary, the military, the church and the educational systems in post-independent Africa are conduits and mechanisms for the propagation of neocolonialism and imperialism. Rev. Father Aaron in $a$ Web and Justice Dan Mowena in The Sins of Babi Yar provide clear justifications for these social ills.
\end{abstract}

Keywords: medium, credibility and vision

\section{Introduction}

The theoretical premises that inform the pronouncements on and analysis of the novels under examination, The Sins of Babi Yar (2012) and In a Web, (2016) are basically from the articulations of Omafume Onoge, Maxim Gorgi, Stephen Greenblatt and Catherine Gallagher. Onoge for example uses the two concepts of critical and socialist realisms as both evaluative tools and as instruments to periodise literary creativity. In this light both critical and socialist realisms constitute a general framework within which the explorations into the identity of the African novel are underscored in literary discourse. In its rootedness in socialist realist epistemology as a philosophical foundation, the post-colonial African novel forms as part of the cultural arsenal to attack the emergent of capitalism in most post-independent African states. The post-colonial African novelist has put his energy freely at the service of all the vices to which his informing political economy is his subject. George Nyamndi in The Sins of Babi Yar and Blessed A. Njume in In a Web have demonstrated that they are observers of, commentators on and participants in the socio-political concerns of their society because a writer writes best about what he knows best, and Nyamndi and Njume have proved that they have mastered their environment.

\section{Statement of the Problem}

The African Novel has encountered an avalanche of critical challenges in the hands of Eurocentric critics such as Charles Larson, Joseph Conrad, Adrian Roscoe and others who openly challenged the credibility of the African Novel in terms of character development, length and the effective use of language. Some even drew hasty conclusions by submitting that the African novel was too sociological. Yet others averred that its sociological and political content has compromised its aesthetic quality. While embracing Chinweizu's 'Afrocentric liberationist perspective', this study debunks Dan S. Izevbaye's 1971 position for a 'suppressed social reference' in literary discourse. Thus, the study attempts an investigation into the efficacy of the mode and medium in Nyamndi and Njume's fictional works.

\section{Research Questions and Hypothesis}

From the problem stated above, the article attempts answers to the following questions: 
(a) Do the sociological and political contents of the two novels compromise their artistic sophistication?

(b) What is the relationship between medium and commitment in the two texts?

(c) Do Nyamndi and Njume write art for art's sake?

(d) What is the link between medium, communication and credibility?

\section{Hypothesis}

From the problem stated and questions posed, and drawing largely from the socialist realism of Lukacsian-Marxist paradigm and the new historicist critical theory, the study underscores the fact that Nyamndi and Njume have effectively explored and exploited their medium of communication in order to deploy crucial thematic concerns in their novels. Hence, form and ideology in both novels are mutually inclusive. In this light this paper sets out to demonstrate how Nyamndi and Njume use their linguistic medium to communicate to the reader credible and authentic themes in their fictional works.

\section{Theoretical Considerations: The Concept of Socialist Realism}

The concept of socialist realism incorporates critical realism and even surpasses it. According to Omafume Onoge the socialist realist artist shows the world as changeable. And because of his historical materialist outlook, his prospective vision is a positive statement on behalf of the revolutionary aspirations of the exploited class. (36)

The African novelists who emerged immediately after independence wrote against the backdrop of critical realism. Some were disillusioned with the failure of independence, yet others were impatient with the celebration of their cultural values. In most of their novels they diagnosed the socio-political malady of their society but did not go beyond diagnosis. As Onoge has observed... after we are impressed by the truth of their criticism, we are left with the question: what next? (35) On that score it could be argued that the conclusions of their works either show an indifference to prospective statements or imply a host of philosophical positions ranging from liberal humanism, nihilism to cosmic pessimism. Some of such novels are A Man of the People, Remember Ruben, Perpetua and the Habit of Unhappiness, The Beautyful Ones are not yet Born, A Wreath for Udomo and No Longer at Ease.

While this was the position adopted by the early African novelists otherwise called the critical realists, African novelists who came after them adopted a more dynamic, radical and revolutionary stand. Some of these novels include Achebe Anthills of the Savannah, Ngugi's Petals of Blood, Sembene Ousmane's God's Bits of Wood, John Nkengasong's Across the Mongolo, Festus Iyayi Heroes and Bound to Violence and Francis Nyamnjoh's The Disillusioned African and Mind Searching. True socialist realism is therefore also critical realism, enriched by the artist's fundamental acceptance of society and a positive social perspective. (Ernst Fischer, 1963: 113) This particular novel with a socialist realist orientation has a different attitude from early pessimistic novel, and it requires always new means of expression. It is this new mode and medium of communication that this study seeks to examine.

Basically, some of the features of socialist realism include: optimism and hope, conscientisation and revolt. Chidi Amuta in The Theory of African Literature outlines the following characteristic features of socialist realism in the following words: "...the essential attributes of socialist realist expression include (a) the use of simple and accessible language (b) a sympathetic portrayal of characters from the oppressed,(c) a sense of patriotism defined in terms of concern with the struggle of socialism"(140). Socialist realist writers must be politically active on the side of the oppressed.

Maxim Gorky, the doyen of socialist realism summarizes these socialist realist features thus:

... it is clear that in addition to the necessity of studying the language and developing the ability to select the simplest, most graphic and colourful words from a literary language, which while perfected to a high degree is nevertheless littered with empty and ugly words, the writer must also have a good knowledge of the past history and of the social phenomenon of contemporary society in which he is called upon to fulfill his dual role of midwife and grave-digger (32-33)

Finally, Es'kia Mphahlele contends that African writers especially critics must always "hammer their theories out of their socialist realism" (84).

The socialist realist novelist believes man's potential for development to be unlimited, without, however, believing in an ultimate paradise- without, indeed, even wanting the fruitful dialectic of contradiction ever to come to an end (Fischer, 113).

The second critical theory that is used in the evaluation of the two novels under study is new historicism. Considering the symbiotic and dialectical relationship that exists between language and ideology in the two novels under study, new historicism is relevant here. Furthermore, the revolutionary nature of Nyamndi and Njume calls for the utilization of socialist realism/Marxist critical paradigm and new historicism.

The new historicist critical theory gained currency in the literary academia in the 1980s as a counter discourse to the 
American text-based approach known as New Criticism. Critics of New Criticism gave an intrinsic analysis of literature, thereby, treating a literary text as an autonomous self-sufficient entity quite separate from society, history or any external causal agent. The new historicists, however, take the contrary view and contend that literature is the product of a particular socio-historical and cultural context and should therefore be interpreted against the background of its context. Hence, its interpretation can only be meaningful and relevant when the historical circumstances under which the text was created are taken into consideration. Proponents of this approach to criticism include Laurence Lerner, Jerome McGann, Irving Howe, Paul Ricoeur, Stephen Greenblatt and Catherine Gallagher.

In summation, the co-relation between literature and history, in the area of New Historicism, is a reciprocal relationship. This approach connotes that it is not only history that influences literature; the reverse can also be true. This explains why Murfin and Ray (1979:239-240) state: "New Historicist critics assume that works of literature both influence and are influenced by historical reality, and they share a belief in referentiality, that is a belief that literature both refers and is referred to by things outside itself'. The above contention demonstrates that literature can also shape the face/phase of history. This means that literature can (re) shape and (re) direct history and vice versa. It is against such a background that Chinua Achebe in Morning Yet on Creation Day contends that,

...an African creative writer who tries to avoid the big social and political issues of contemporary Africa will end up being completely irrelevant-like that absurd man in the proverb who leaves his burning house to pursue a rat fleeing from the flames (Chinua Achebe, 1975:78).

Another critic, the Kenyan celebrated writer, Ngugi wa Thiong'o in Writers in Politics, argues that every writer is a writer in politics, but the question now is whose politics. With this in mind, it will not be surprising if the two authors preoccupy themselves with politics in the novels under examination.

\section{Textual Analysis}

George Nyamndi and Blessed A. Njume in their respective novels, The Sins of Babi Yar and In a Web have demonstrated that literature, especially the novel is an agent of social change. Using language as an effective medium of communication, they have addressed one of the fundamental themes in African contemporary politics: power; and the fundamental question raised is: for what reasons do we acquire power? Is it to serve mankind or to oppress the masses? The abuse of power is demonstrable in all facets of life in the novels: In Njume's In $a$ Web for example, from primary through secondary schools to the university, corruption is rife. The obnoxious activities of some politicians and church officials are debunked in both novels. Even primary and secondary schools which are considered as the formative phases of leadership, the pupils and students are extremely corrupt. The existence of corruption at this formative stage leaves the reader with the impression that the future is bleak in Ngonda the novel's setting; here the pupils and the students are prone to corruption; those who refused to take part in manual labour look for a way to bribe the Senior Prefect:

Some students attempted buying their way by giving little tips to some of the prefects. They really pay high so as to get away from the impending doom. The Labour prefect collected the bribe on behalf of the other prefects who were in support of the deal (p.90).

The author insinuates that even at this formative stage, the future leaders of Ngonda are capable of giving and accepting bribes. This paints a pessimistic future of Ngonda in particular and the Cameroonian society in general where corruption has eaten deep into the marrow and fabric of the Cameroonian body politic. In fact corruption has been institutionalized in this society.

Before I delve into the analysis of the novel, it is important to decode the encoded message in the title, In a Web. A web as we all know is a trap. The web in the context of the novel is a dense symbol with metaphorical possibilities. It depicts the fact that those who are power drunk are seduced by money and are susceptible and vulnerable to this trap/web. From secondary school to the university, the leaders are caught in this trap. Government officials and ministers are the most vulnerable for this web because they are easily seduced by money. Finally, the church leaders who are supposed to provide moral light in the society are found wanting.

The church in every society should articulate and express the moral consciousness of the people; she is supposed to fight against all societal ills but in Ngonda, the church incarnates the very vices she is supposed to fight against. The church officials who should be exemplary in leadership are found wanting. Reverend Father Aaron is a symbolic representation of men of God who preach virtue and practice vice. This particular priest embezzles money meant for church projects. He has become avaricious, proud, arrogant and covetous. As the author puts it, Father Aaron was taken by power and he lost all his sense of respect and decency. He became too avaricious for their liking (p.95). Furthermore, he lies, creates division in the house of God and also uses his homilies to get at his detractors. He entertains gossips and scolds at his Christians without love. He refuses Father Emma the Parish car and even calls him a thief: "on several occasions, he openly contradicted Father Emma, telling the Christians to listen only to him as he was the Parish priest. He told them once never to go to Fr. 
Emma to have their Christian contribution cards marked because the latter was a thief (96).

Father, Aaron constitutes a sharp contrast to Father Emma who is humble. The novelist exploits contrast as a communicative medium to demonstrate the fact that in spite of Father. Aaron's cruel and queer behaviour, there are some men of God who are still trust worthy. While Father Aaron is a replica of Big Father in Kenjo Jumbam's The White Man of God, Father Emma represents Small Father in terms of their approaches to spiritual matters. The author insinuates that any Christianity without love is empty Christianity because Christ died to save mankind.

Nyamndi also articulates similar thematic concerns in his novel. To understand Nyamndi's ideological posture in The Sins of Babi Yar, it is important to decode the encoded message in the title. Babi Yar is Russia's own version of Auschwitz. Here thirty-five thousand men, women and children were shot and put down in a ravine to be buried; or then six million men, women, children cremated, incinerated, roasted and killed. Nyamndi draws a parallel between the Sanko prison in Tole, the novel's setting and Babi Yar and Auschwitz. According to the narrator, Babi Yar, Auschwitz, Sanko, Robben Island and Tcholire are similar in many ways: they are all places of deprivation and places of revelation (118). From this explanation, Tole under the leadership of people like Justice Dan Mowena and Motine Swaibu, the people are in hell. A whole life of promise is raked by the greed and graft of a callous leadership personified by Dan and Swaibu. These two are corrupt, boastful, crude and brutal. Living in Tole is synonymous with living either in Robben Island, Babi Yar or Tcholire. These are notorious prisons reputed for their mental, physical and psychological tortures and torments.

In every dictatorial system like the ones in Tole and Ngonda, the law and the military are inseparable. Peter Barry in Beginning Theory quoting Louis Althusser says state power is maintained by what Althusser terms "repressive structures, which are institutions like the law courts, prisons, the police force and the army which, operate, in the last analysis by external force (p.164). This relationship is clearly demonstrable in Nyamndi's novel wherein the President of the Tole Magistrate Court, Justice Dan Mowena and Motine Swaibu, the Chairman of the Tole Credit Union use their powers to oppress and subjugate the common man represented in the text by the two committed investigative journalists (Levi and Shechem) who double as environmental activists and the primary school teacher, Efuet Martin. Swaibu has siphoned the funds of the Credit Union to buy justice and corrupt the law. Swaibu's relationship with Justice Dan and the law enforcement officials raises a lot of suspicion; they have something in common: to twist the logic of the law.

Justice Dan is paid to dispense justice but he perverts the very justice he is paid to safeguard. Justice in the world of The Sins of Babi Yar is sold for the highest bidder. In his chat with his partner in crime, Motine Swaibu, Justice Dan Mowena defines what justice means to him using the glass table in his office. The glass table in the novel is a dense symbol with metaphorical possibilities. He starts by dismissing the transparency of his predecessors like Justice Ekosso and Mandiba who incarnate genuine justice. To Justice Dan, these judges were too straight in matters of the law. Hear him: "And where has that straightness taken them? They came to learn that the law was not about blind straightness but more about interest. That was a lesson I lost no time imbibing right in the school of magistracy....He turned towards the table and fixed it with a look as if of solicitation. The black wood, you see it? I had to contain the unchecked transparency of the glass table "by trimming its shine to size" (9). When Justice Dan came to that office, the table which he uses was entirely a glass table symbolizing transparency in the dispensation of justice, but he intentionally "trims the shine to its size." This metaphorically and symbolically means that Justice Dan's notion of justice is that there is no justice without some degree of injustice. This is dangerous because without justice there cannot be peace. His own justice has a face and a name (92).

The massive black spot under the glass table signifies the corrupt aspect of justice. That is why after having crippled the Credit Union and rendering it bankrupt, and after Levi's investigations which point to the fact that Swaibu is behind this financial scandal, Swaibu still gets off the hook of the law. He uses the very money siphoned from the Credit Union's coffers to buy justice. According to the author, Swaibu's relationship with magistrates, lawyers and the police is comparable to the bond that exists between flies and fetid meat (p. 45). This metaphor of flies crowding over rotten meat emphasizes the decayed nature of the judiciary system in Tole.

The second instance in which Swaibu has his way after committed crimes that should have been punished by the law is when he eliminates his three rival cattle owners. The hand hired to execute this macabre act is apprehended and confesses to the triple murder. And Levi, the investigative journalist investigates the crime and his findings lead to the arrest of Swaibu, but the case is withdrawn from Magistrate John Kambini for the simple reason that the case was too complex to be handled and sent to Justice Dan Mowena who is Swaibu's partner in crime (52). Justice Dan and Swaibu are the law; the state commits crimes and its demagogues talk them into virtues. The narrator explains: "Motine Swaibu knew that his tandem with Dan Mowena was impregnable in its power to bend situations. When money was put at the service of the law, made to blind the eyes of justice, used to blunt the retributive sting of the law, the likes of Shechem did not walk away from Sanko prison free" (162).

Another classic episode of the perversion of justice in the world of The Sins of Babi Yar is seen in the number of those 
detained without trials; some have been there for three years and others for four years without trial: Hear some of the detainees: "Me four years" "Three years I have been here." "Never tried, me. I have lost count!" (88) But when the famous Gang of Six who rape and slay at random were arrested and taken to Sanko, they were there only for six days and Justice Dan Mowena offers them safe haven from a vendetta. (88) The second incident is the arrest and detention of Efuet Martin for the misappropriation of school fees, whereas it was the Head Master who did that. Hear Efuet: "They said I ate the money but that is not true. I'm not the kind...now or ever. The HM. He used it to build his house, then sent two cows to Dan Mowena with the rest" (87). This incident happened some two years back and Efuet has been in detention without any trial. The point expressed here is that the real criminals are loitering and roaming the street of Tole, while peace loving and law abiding citizens are in the Sanko maximum prison without trial. This is one of the ills that Nyamndi decries and indicts in his novel. The novelist seems to suggest that the net of justice is designed in such a way that only the innocents are caught in that net and the real criminals have their way out.

Levi and Shechem who symbolically stand for the truth, justice and equity are arrested and put behind bars for pointing their fingers in the right direction; for denouncing wrongdoing. These two journalists are not the kind to let injustice off the hook that easily (p.48). The author insinuates that Tole is not a safe society for committed journalists of the caliber of Levi and Shechem.

Another interesting and innovative medium of communication employed by Nyamndi in his novel is the use of poetry/songs in prose fiction. The juxtaposition of prose and poetry lends some credibility to his work. Emotions are best expressed in poetry because poetry is the most hermetic genre of literature. He uses songs/poems to bring out poignant and pertinent themes in the novel. After the untimely death of Levi, Shechem searches through some of the things Levi has been writing and comes out with the following poems scripted by him. One of such poems is this four lines poem titled "The Grave."

I love the grave

The eternal sleep

The final silence

Of muted walls. (144)

The gloomy atmosphere expressed in this poem intensifies Shechem's melancholy; but at the same time it provides him reason to believe that all along he had been dealing with a mind resolute enough to place his pleasures distantly beyond worldly sanction. Death is euphemistically described as sleep because of the peace that accompanies death as opposed to the oppression and the perversion of justice being perpetrated and perpetuated by the likes of Justice Dan and Swaibu. In this other poem without a title, Nyamndi writes:

I am tired waiting for death, tired

Tired waiting to see it, death

They talk about it

Fear it

But me

I long for it

I rejoice at the thought

God has prepared salvation

Let men enjoy it!

Now I am dead.

I can see the open hands of God's messengers

Welcoming me

First into reproach

Then into glory! (144-5)

This poem celebrates death over life because in Tole the people are living corpses. Levi's death has a tremendous impact on Shechem's psyche. He thinks that Levi has fought the good fight against social injustice even though his end is untimely. In his subconscious mind Shechem imagines that he is dead, and the messengers of God welcome him first by reproaching him for not completing his assignment on earth, but finally accept him into glory for at least trying to question the injustice perpetrated by Justice Dan Mowena. The lesson drawn from this poetic piece is that we should 
fight against social injustice so that even if we pass on eventually, the message will be that we fought.

The two poems are therefore philosophical reflections on life and underscore the inanity of human existence as Shechem puts it: "There are times in life we question the very sanity of our earthly stay. This is one of such time. We plan, forecast, caress hopes and dreams; then bang, and all is brought to naught. We quarrel and fight, hate and spite; then bang, and we are stuck with the foolishness of our hatred and spite. What a joke of our earthly existence" (149).

The emptiness of life is vividly expressed in the untimely death of Levi in these two poems. People listen and hear nothing; they look and see nothing; reach out and touch nothing; they ask and have nothing. These are very terrifying, yet real in the world of The Sins of Babi Yar.

The same themes of perversion of justice, corruption and bribery are developed, deployed and well articulated in Njume's In $a$ Web. The author indicates that the law enforcement officers who should maintain peace and tract down corrupt officials encourage corruption and injustice. The fundamental questions raised in the novel are: what can a people do to right the wrongs of a corrupt and decayed society? Of what critical relevance is the medium of communication in the interpretation and understanding of the novel? What is very visible in Njume's novel is his preoccupation with the contemporary Cameroonian socio-political reality and the searchlight which he casts on the close relationship between the people's representatives and the neocolonial government which is being teleguided by the imperialists. This highlights one of the major pitfalls of national consciousness, namely the betrayal of indigenous trust by the elected representatives. That explains why the very critical and vocal Nebengu falls prey when given power and eventually becomes a monster. Even in the church setting, it is only when Rev. Father Aaron is confirmed Parish priest that the other side of him comes out; he becomes dictatorial, autocratic and ruthless. In fact, this is where the significance of the title of this novel resides. As the saying goes, power corrupts and absolute power corrupts absolutely.

In $a$ Web is a scathing indictment directed at four different categories of leadership in any contemporary African society: the government Ministers and Mayors, the Church officials, precisely the Priests, the police and gendarme officers who collect money from drivers at checkpoints, students' leaders at both the elementary and secondary levels and the university administration and lecturers. At the level of the university officials are appointed on tribal lines, and this has resulted in conflict and strife because the very ones who are qualified are not appointed. The novel, therefore, can be described as a satire on religious, government and academic leaders as will be seen in the analysis that follows.

The novel narrates the story of two friends, Nebengu Godwin and Sanga Moki who are both teachers in Government High School Ngonda, the setting of the novel. These two are very critical of the government represented in this constituency by Hon. Dr Nekena, MP for Iriba -Ngomba constituency. Encouraged by both his friend Sanga Moki and Rev Father Aaron, Nebengu puts in his candidature to challenge Hon Nekena. He would eventually win but his performance as MP is worse than that of Hon Dr Nekena and he is voted out and interestingly, Dr Nekena is brought back as the MP for Iriba-Ngomba constituency. The author emphasizes the danger of the re-cycling syndrome in African contemporary politics where the same people are flushed out of the government for one crime or the other but are brought back without any convincing reason.

At the end of the novel, Hon. Nebengu Godwin who had bartered the people's interest for his own selfish ends and was rejected by the very people who had voted him to power is appointed Minister of Public works, an appointment received by the population with mixed feelings. Drunken by power and seduced by money, Nebengu embezzles fifty billion ear-marked for the rehabilitation and maintenance of the bad roads which the author pictorially presented on page 14 of the novel. He falls into the drag net of the Anti-corruption team, is arrested, tried and sentenced for twenty-five years. He commits suicide a few days after. The arrest and imprisonment of Minister Nebengu sent shock waves down the collective spine of government officials as they try to cover up their tracts of bribery and misappropriation of public funds.

The plot of the novel is linear- logical and sequential having twenty chapters. The story is told in both the second and third person points of view, characterized by a plethora of dialogues with their attendant dramatic effects. In a Web is set in a fictional village called Ngonda which is divided into ten quarters. In this community the people lack both the physical/literal and spiritual/metaphorical lights; and that explains why the lives of people like Nebengu Godwin who go to Church and are members of a choir are still characterized by greed and blatant covetousness when they are given power. Like the Catechist, Pa Mathew, in Kenjo Jumbam's The White Man of God, the people of Ngonda constitute a classic hybrid postcolonial subject in whom neither Roman Catholicism nor African traditionalism is their life style (p.13).

In Jumbam's text when the kibaranko, the deadliest juju of the land is unmasked in public, the person behind the mask is shockingly Pa Mathew, the catechist of the church. In Ngonda, the people go to church on Sundays but still hold tight to their tradition and culture. To make things worse is the presence of priests like Rev. Father Aaron who demonstrate a penchant for materialism. The misappropriation of church funds and his snobbish attitude towards his own Christians put his character to question. Like Big father in Jumbam's text again who abuses his Christians during mass, Father 
Aaron uses his homilies to chastise and embarrass his Christians. He is rude and insolent. He tells lies, creates division in the church and even steals church money. He declares you his enemy if you have anything to do with his collaborator, Father Emma (95-6).

Ngonda is pro-the ruling government, but ironically and paradoxically, she lacks the basic road infrastructure, social amenities like hospitals, electricity etc (13). Ngonda that voted 97 percent in the previous Presidential election lacks these basic things. To add to this, Ngonda has got illustrious sons and daughters in government like Dr Daniel Nanje of Lobe town who was appointed Secretary General in the Ministry of Education, Dr Mrs. Mar Bernadette Esoh Eyome from Bekora village who was appointed Technical Adviser to the PM (70). Like the saying goes, when your own people are on top of a plum tree you will eat black plums, but in the case of Ngonda, "only dry leaves are given to them", as the author puts it (22). This is a betrayal of indigenous trust; in fact, this is the treacherous reality of today's self-governing African nations. The metaphor of the black plums signifies comforts and fulfilment which are features of the benefits derived from the nation's wealth, while dry leaves symbolize poverty and misery that characterize the neglected in the society.

If the writer must discover the permanent and essential qualities of human nature, he must come to terms with his own feelings as educated by his own sensibility and by his own past. In addition, he must think long and deeply about the veracity of his own experiences. Only in this way can he/she learn to portray truly the universal thoughts and passions of mankind. In $a$ Web is a political reflection and meditation on the imperative of moralizing and Christianizing our body politic.

The outline though broad, nevertheless encapsulates a number of themes through which Njume explores the nature and extent of neocolonialist control and exploitation of the state of Cameroon in particular and Africa in general. As the author commented during the launching occasion of the novel, the nature and limitation of neocolonialism constitute the core of In $a$ Web.

The use of Pidgin English In $a$ Web creates an atmosphere of a compartmentalized society. Njume exploits code-mixing and code-switching as a medium to communicate the endemic nature of corruption in Ngonda, the fictional setting of the novel. The scene is where the car of Ukwa, a commercial driver gets stuck in the mud because of the bad roads. Coincidentally, the Lord Mayor of Motiti Rural Council, a council after Mundemba town is in this bus and as people come out to push the car, he refuses. Two things are evident here: the first issue is the inscription on Ukwa's car which bespeaks of the normalization of corruption: "Scratch ma back, I scratch ya own" (16). According to the narrator, Ukwa is as rude as a brute. And the car and its title and its driver are just a representation of the nature and state of affairs of the Division in particular and the country as a whole (16). What is particularly lamentable is Ukwa's emotional outburst when the Mayor refuses to push the car. Hear Ukwa: "Ase eh Chef, whoside you too di go? Na who go push motor when man pikin like you di run poto poto? I beg come back come push oh Sah, like we go sleep for here (17). But when he is reminded that he was talking to the Mayor, Ukwa even becomes more abusive: "Mayor whe e mean say whetti?"... "No bi na them di chop government money?" Make he too push so that he go see'm as we di suffer" (16). Ukwa articulates the view of the common man who feels abandoned by the very government he was cajoled and hoodwinked into voting for. He goes on to decry the system in place by saying a lot of nasty things: "No bi na whona di chop government money? Na who na get government noh? Whona dey for winning team" (18).

Njume's ability to switch from Standard English to Pidgin English lends credence to his communicative skills. In Marxist critical discourse, the existence of two levels of a particular language underscores the compartmentalization of such a society: the haves and the have-nots co-exist, with the haves swimming in the cesspool of ill gotten wealth while the have-nots languish in abject poverty. Ukwa's emotional outburst in the novel is a scathing indictment on the government that has left its own people to their own devices. While some swim in the cesspool of ill gotten wealth, others languish in misery and pains. The people are deprived of some basic amenities such as: pipe borne water, roads, drainage system, hospital and health centres. Even where the government manages to provide a health centre, there is no resident medical doctor. From Ukwa's vituperative remarks, it could be argued that the people perceive the government as a problem and not a solution to their plight since she cannot provide opportunities for both individual and collective fulfilments (67).

What is particularly lamentable is the fact that this very people voted for the government in place; that is why Ukwa uses the expression, "Whona dey for winning team." (18) 'The winning team' in Cameroon politics is a metaphor for those who belong to the ruling Cameroon People's Democratic Movement (C.P.D.M) of Mr. Paul Biya. The predicament of the people of Ngonda is metaphorically captured in this horticultural imagery and paradoxical statement which underscore the vacuous rhetoric in post colonial African politics: "Though our own man is on the tree, all what we get are the dry leaves; not the so much desired black plums; not even the red ones for consolation sake" (22).

The use of pidgin English as a medium of communication that enhances credibility in this study is not only limited to In $a$ Web; Nyamndi also exploits this device effectively. The assertion Nyamndi makes on page six about women in this text that, "Marriage does not change the essential nature of women," finds expression in Bertha's behaviour. Nyamndi makes the point more poignant when he adds that, "All women are responsive to one melody: money melody" (6). 
Bertha, Shechem's wife takes advantage of her husband's detention and is messing around with men. But when Shechem is released and he returns home, Bertha is nowhere to be found, but Jelena, Shechem's neighbour explains to Shechem the horrible things that have been happening in his house in his absence: "I don see kan kan tin for that yu haus. But as I talk, if $i$ kam back no drive am" (192). And Shechem replied: "I no go drive am, as you talk" (192). The author uses this code mixing and code switching to underscore the frailty of women. It was Hamlet in William Shakespeare's Hamlet who laments that: "Frailty thy name is woman." The unfaithful nature of women is personified in this text by Bertha's unfaithfulness; she abandons their only daughter, Kun at the mercy of their neighbour, Jelena, and disappears to the city with a man (192). In Nyamndi's text, therefore, there are two levels of betrayal, namely at the family level and at the national level. The point being made here is that if the family which constitutes the nucleus of the society is not intact, the entire society is threatened.

The socialist realist approach to literary appreciation shows the world as changeable; and because of its materialist outlook, its prospective vision is a positive statement on behalf of the revolutionary aspirations of the exploited classes in the society. Ukwa's criticism of the government is intended chiefly to bring about a change in mentality of those who wield political power in the society. According to the doyen of the concept of socialist realism, Maxim Gorgi, the socialist realist writer must play the dual role of a grave-digger and mid-wife. That is, after describing and highlighting the social ills of the society, the writer should proffer solutions, and Nyamndi and Njume have done this in their respective novels. Even though the sense of despondency is profound in both texts, they end with some hope and optimism. The pessimism in In a Web is that after Hon. Dr Nekena, the MP for Iriba-Ngomba has disappointed the people, Nebengu Godwin who in the beginning of the novel is perceived as a grain of hope is even worse than him when he became the MP for Iriba- Ngomba and eventually Minister of Public Works. But the good news is the success of Nebengu's son Nanji who at the end of the novel becomes a diplomat and serves his country with honesty and sincerity.

In The Sins of Babi Yar, the wheel finally comes full cycle and Justice Dan Mowena and Motine Swaibu are arrested and taken to the capital to face the music of justice as the court clerk explains when he announces Shechem's release: "For three weeks a team of legal experts investigated the Tole Magistrate Court records from as far back as when Dan Mowena became the President. The things they unearthed are beyond our imagining" (171). Both novels end on a note of optimism reinforcing the socialist realist vision of the two novelists.

A writer in a changing society is a prophet, a seer, a conscientizer, a political adviser and a moral legislator. Nyamndi and Njume have fulfilled some of these functions in their novels. The authors' ideological framework finds artistic expression in a number of aesthetic features concurring T.S. Eliot's submission that the greatness of literature is not determined by literary standard alone; but whether it is literature or not must be determined by literary standards. Since language is the artistic vehicle by which meaning is conveyed in its ideological essence, the novelists have exploited a gamut of novelistic techniques to reinforce their thematic preoccupations: they include: dialogue, suspense, the use of Pidgin English, paradox, irony, the journalistic technique, biblical allusions and symbolism. They use these devices to bring out the various themes that permeate and pervade their works; for example, the abuse of power, bribery and corruption, misappropriation of public funds, the perversion of justice, fraud, favouritism and nepotism.

Finally the recycling metaphor is another effective device Njume uses to underscore the underdevelopment agenda in Ngonda. The ministers in the world of In a Web constitute a clique of operators and manipulators who only move from one ministry to another. Secondly, the right persons are not placed in their area of competence. These, Njume decries because they bring about underdevelopment in any society. Whenever there was a rumour of change in the system it was the same people moving from one ministry to another. The names of the same people keep on repeating year in year out each time there is any cabinet reshuffle. As the author puts it, "Old hands were simply recycled" (110). Furthermore appointments in Ngonda are not based on competence but are based on one's loyalty to the government in power. Like The Daily Chronicles which is a pro-government in Chinua Achebe's A Man of the People states, a man does not need to have a $\mathrm{PhD}$ in Economics before he is made minister of Finance, what matters is his loyalty to the government. This situation is seen in Ngonda. For example someone who studied abroad and took a PhD in International Law is appointed minister of Agriculture. This misplace of priority reinforces the underdevelopment agenda in the novel (114).

According to Thomas De Quincey, there are two types of literature: the first is the literature of knowledge which is largely embodied in historical and scientific works. This type of literature passes away; the second is the literature of power, which represents the enduring works of the creative imagination. Its function is to move us. It speaks to the higher reason or understanding, but always through affections of pleasure and sympathy. More rare than truth is power, that is deep sympathy with truth. In contradistinction of literature of knowledge, the literature of power concerns itself with the great moral capacities of man. Both The Sins of Babi Yar and In a Web fall in the second category because these are works whose mission is primarily to transform and change the society.

The two novelists preoccupy themselves with the concept of power in African contemporary politics. The two fundamental 
questions raised in the two novels are: What is the essence of acquiring political powers? With regard to this question, the Somalian critic, Nuruddin Farah provides an answer to this question for us when he opines that, "The African politician is a blind man, he moves only in one direction- toward himself. The Greek tragedian of old, Sophocles says that if you want to know somebody well, give that person power. It is only when the very vocal and critical Nebengu Godwin is given political powers that his real colours come out. It is only when Reverend Father Aaron is confirmed the Parish priest that we know his true character. Finally, Justice Dan and Swaibu are epitomes of those who acquire power to oppress and not to serve. The grim irony is that as Minister of Public Works, Nebengu Godwin siphons money meant for the rehabilitation and maintenance of roads even when his own constituency does not have roads.

The second fundamental question raised in In $a$ Web that begs for an answer is: Is it the politician who is dirty or it is politics itself? The author answers the question by making a passionate appeal to Cameroonians to register massively on the electoral register because as he puts it "bad politicians are elected when good citizens refuse to vote" (111).

\section{Conclusion}

In concluding this article, it is important to restate its hypothetical contention. The study set out to investigate the efficacy of the medium of communication and the themes deployed by these modes of communication in Nyamndi and Njume's novels. My investigation revealed that the two novelists have effectively exploited and explored different modes of communication that have enhanced their ideological postures. The worlds of the two novels, The Sins of Babi Yar and In a Web are fraught with societal ills such as the miscarriage of justice, the perversion of justice, corruption, bribery and the abuse of power. All these themes are made credible, thanks to the medium of communication employed by the two novelists.

\section{Acknowledgements}

I am indebted to the Ministry of Higher Education in Cameroon for introducing in 2009 the Modernization Research Allowance in Cameroonian State universities which has boosted and revamped research in the country. I am also grateful to the research allowance paid by the Faculty of Arts, University of Buea for research related activities.

\section{References}

... (1975). Morning Yet on Creation day. London, Heinemann.

Achebe, C. (1966). A Man of the People. London; Heinemann.

Barry, P. (1995). Beginning Theory. Manchester: Manchester University Press.

Besong, B. (1993). "Keynote Address" in Lyonga, et al (eds) Anglophone Cameroon Writings. Bayreuth: University of Bayreuth, pp. 17.

Chinweizu et al. (1980). Toward the Decolonization of African Literature. (Vol. 1) Enugu: Fourth Dimension Pub. Co. Ltd

Fanon, F. (1967). The Wretched of the Earth. London: Penguin Group.

Fischer, E. (1963). The Necessity of Art. New York. Penguins Group.

Fonlon, B. (1978). The Genuine Intellectual. Yaounde: Buma Kor,

Gorgy, M. (1971). “On Socialist Realism”. In C. V. James. Socialist Realism in Literature and Art. Sussex University. OI Spirinova.

Gwangwa'a, G. (1995). Cry of the Destitute. Limbe: Nooremac Press.

Jumbam, K. (1980). The White Man of God. London: Heinemann.

Lyonga, N., Breitinger, E., \& Butake, B.(eds.). (1993). Anglophone Cameroon Writing. Bayreuth: Bayreuth University

Mazrui, A. (1976)). The Trial of Christopher Okigbo. London: Heinemann

Ngugi, W. T. (1997). Writers in Politics: A Re-engagement with issues of Literature and Society. Oxford: Heinemann

Onoge, O. (1985). “The Crisis of Consciousness in Modern frican Literature.” In George M. Gugelberger (ed) Marxism and African Literature. Trenton, New Jersey; African world press, Inc.

Tyson, L. (1999). Critical Theory Today: A User-Friendly Guide. New York and London: Garland Publishing Inc, G.V.

\section{Copyrights}

Copyright for this article is retained by the author(s), with first publication rights granted to the journal.

This is an open-access article distributed under the terms and conditions of the Creative Commons Attribution license which permits unrestricted use, distribution, and reproduction in any medium, provided the original work is properly cited. 